\title{
Serum Prolactin and ImmunoglobulinE Levels in Psoriasis Vulgaris before and after NB-UVB Therapy
}

Mamoun Elsayed Shalaby ${ }^{1}$, Hassan M Hassan ${ }^{1}$, Mohammed I Aref ${ }^{2 *}$ and Asmaa D Ebeid ${ }^{1}$

${ }^{1}$ Department of Dermatology and Venereology, Faculty of Medicine, Al Azhar University, Egypt

${ }^{2}$ Department of Clinical Pathology, Faculty of Medicine, Al Azhar University, Egypt

\begin{abstract}
Background: Psoriasis is a chronic, inflammatory, T-cell mediated autoimmune disease. Many data demonstrating a significantly increased serum levels of both prolactin and IgE in patients with psoriasis vulgaris and reporting an association between their level and psoriasis severity. Existence of prolactin receptors on epidermal keratinocytes provides more support for the hypothesis that prolactin might have a role in the etiogenesis of psoriasis.

Objectives of the study: It was aimed to estimate serum prolactin and immunoglobulin $E$ levels in psoriasis vulgaris before and after NB-UVB therapy.

Patients and methods: Fifty patients were submitted in this study. Severity of psoriasis was calculated using PASI score

Results: The results showed the following; a statistically significant difference between patients before and after NB-UVB therapy regarding PASI score $(P=0.001)$, a statistically insignificant difference between patients before and after NB-UVB therapy regarding prolactin level $(P=0.06)$, a statistically significant difference between patients before and after NB-UVB therapy regarding IgE level $(P=0.0003)$, a statistically insignificant correlation between PASI score and prolactin level before NB-UVB therapy $(P=0.506)$, a statistically insignificant correlation between PASI score and prolactin level after NB-UVB therapy $(P=0.793)$, a statistically insignificant correlation between PASI score and IgE level before NB-UVB therapy $(P=0.074)$, and a statistically significant correlation between $P A S I$ score and lgE level after NB-UVB therapy $(P=0.01)$. Conclusion: The present study concluded that serum prolactin level is elevated in psoriasis vulgaris but there is no correlation of its level with psoriasis severity. Also, serum IgE level is elevated in psoriasis vulgaris and there is a significant correlation between its levels with psoriasis severity.
\end{abstract}

Keywords: Psoriasis prolactin; IgE; NB-UVB therapy

\section{Introduction}

Psoriasis is a chronic, inflammatory, T-cell mediated autoimmune disease that affects mainly skin, nails and joints. It is one of the most common inflammatory skin diseases, affecting 2-3\% of the population. Psoriasis is characterized by the presence of sharply demarcated, red plaques with adherent silvery white scales and a tendency for symmetrical distribution over the body $[1,2]$.

Prolactin is a neuropeptide secreted by the anterior pituitary and it has an important immunomodulating properties. Serum prolactin levels were shown to be increased in psoriatic patients, to be correlated to severity, and to decrease after treatment. Thereby, it supports the potential role of prolactin as a biologic marker of psoriasis [3]. Existence of prolactin receptors on epidermal keratinocytes provides more support for the hypothesis that prolactin might have some role in the etiogenesis of psoriasis [4]. Prolactin acts on human keratinocytes and enhances the production of chemokine (CXC motif) ligand (CXCL) 9, CXCL10 and CXCL11, which preferentially attract Th1 cell infiltration into psoriatic lesions [5].

IgE is one of five isotypes of human immunoglobulins [6]. It is involved in the pathogenesis of many allergic diseases [7]. Increased serum IgE concentrations have been documented in patients with psoriasis [8]. The possible association of serum IgE levels and psoriais has been reported [9]. Overproduction of IgE is usually Th2 cell determined $[10,11]$. The Th2 cytokines IL- 4 and IL-13 are required signals for IgE synthesis. Keratinocytes do not produce IL-4 or IL-13 but they are involved in IL-4 or IL-13 induced biological effects.

Narrow band ultraviolet-B (NB-UVB) phototherapy is a standard treatment for psoriasis. Its mechanism of action is incompletely understood and has mainly been studied in vitro and in mice. Locally, NB-UVB therapy reverses several pathological alterations in psoriasis: the number of epidermal $\mathrm{T}$ lymphocytes and dendritic cells decrease during phototherapy $[12,13]$.
T cell exhibit a functional shift toward less IFN- and more IL-4 production after UVB treatment $[14,15]$ and NB-UVB therapy reduces keratinocyte proliferation [13].

\section{Aim of the Work}

The aim of this study was to estimate serum prolactin and immunoglobulin E levels in Psoriasis Vulgaris (PV) before and after NB-UVB therapy and correlation with psoriasis severity.

\section{Patients and Methods}

This study was a clinic based study. Patients were from attendants of Department of Dermatology and Venereology at Damnhour National Institute. Fifty five patients were enrolled in this study, but 5 patients were missed as they did not continue their phototherapy sessions. So, 50 patients were submitted to the present study during the period from April 2014 to December 2014. The patients were 35 males and 15 females. Their age was between 15 and 66 years.

An informed consent was obtained from all patients about sample taking and exposure to NB- UVB phototherapy.

*Corresponding author: Mohammed I. Aref, Department of Clinical Pathology Faculty of Medicine, Al Azhar Universty, Cairo, Egypt, Tel: 02-1154000554; E-mail: aref48@mail.com

Received July 23, 2015; Accepted September 11, 2015; Published September 17,2015

Citation: Shalaby ME, Hassan HM, Aref MI, Ebeid AD (2015) Serum Prolactin and ImmunoglobulinE Levels in Psoriasis Vulgaris before and after NB-UVB Therapy. Med chem 5: 432-436. doi: 10.4172/2161-0444.1000296

Copyright: @ 2015 Shalaby ME, et al. This is an open-access article distributed under the terms of the Creative Commons Attribution License, which permits unrestricted use, distribution, and reproduction in any medium, provided the original author and source are credited. 


\section{Patients}

Inclusion criteria: Patients diagnosed with generalized plaque type psoriasis vulgaris.

\section{Exclusion criteria}

1. Patients on topical or systemic therapy for psoriasis including steroid.

\section{Patients with allergic or infectious diseases.}

3. Causes of secondary hyperprolactinemia: pregnancy, lactation, hepatic diseases, renal diseases, endocrinopathies, psychic patients and alcohol intake more than $20 \mathrm{ml}$ per day.

\section{Every patient was subjected to the following}

History taking: Personal and psoriatic history as well as other skin diseases or drug intake.

a- Personal history: name, age, sex, marital status, address, occupation, and special habits of medical importance.

b- Psoriasis history: onset, course, duration of illness and history of previous or current treatment for psoriasis and date of stopping the drug.

c- Past history of systemic diseases, other skin diseases and drug intake.

\section{Examination}

a- Complete general examination.

b- Complete cutaneous examination: Clinical assessment of psoriatic lesions was done to determine the distribution, clinical variants, skin type (for phototherapy dosing) and the extent of the psoriasis.

\section{Assessment of psoriasis area and severity index (PASI) score according to Naldi, Gambini and Malkic et al. [16,17]}

A clinical scoring system is a system translating a "clinical judgment" into a scale. PASI score was adopted and done for all patients as an indication of degree of severity. PASI contain 4 items: surface area, severity of erythema (redness), induration (thickness), and desquamation (scale) evaluated for 4 body areas (head, trunk, and upper and lower extremities). The four main anatomic sites are assessed: the head $(\mathrm{h})$, upper extremities $(\mathrm{u})$, trunk $(\mathrm{t})$ and lower extremities (l) roughly corresponding to $10 \%, 20 \%, 30 \%$ and $40 \%$ of body surface area, respectively.

The PASI score is calculated from: PASI $=0.1(\mathrm{E} h+\mathrm{I} h+\mathrm{D} h) \mathrm{A} h+$ $0.2(\mathrm{E} u+\mathrm{I} u+\mathrm{D} u) \mathrm{A} u+0.3(\mathrm{E} t+\mathrm{I} t+\mathrm{D} t) \mathrm{A} t+0.4(\mathrm{E} l+\mathrm{I} l+\mathrm{D} l) \mathrm{A} l$, where $\mathrm{E}=$ erythema, $\mathrm{I}=$ induration, $\mathrm{D}=$ desquamation and $\mathrm{A}=$ area. $\mathrm{E}, \mathrm{I}$, and $\mathrm{D}$ are assessed according to a 4 -point scale where $0=$ no symptoms, $1=$ slight, $2=$ moderate, $3=$ marked, and $4=$ very marked.

$A$ is assigned a numerical value based on the extent of lesions in a given anatomical site:

1 (<10\%); 2 (10-29\%); 3 (30-49\%); 4 (50-69\%); 5 (70-89\%); 6 (90$100 \%)$.

The PASI varies in steps of 0.1 units from 0.0 to 72.0 . The highest score represents complete erythroderma of the severest possible degree.

\section{Patient instructions}

All the patients were instructed to the following:
Stopping topical and systemic anti-psoriatic therapies for at least one month before starting the study and during phototherapy.

\section{UVB phototherapy}

The whole body irradiation with NB-UVB was performed delivering NB-UVB in the range 310 to $315 \mathrm{~nm}$ with a peak of $312 \mathrm{~nm}$. We used the Daalvin_24 lamps; both UVA and NB-UVB. Patients were treated 2 times a week with a starting dose according to skin photo type for complete 24 sessions. Efficacy of treatment was assessed by means of PASI score before and after NB-UVB. Dosing guidelines for NB-UVB was according to skin types according to Menter et al. [18].

\section{Serological evaluation}

Serum sample collection and storage: Three blood samples were collected from each patient: the first was before initiation of NB-UVB phototherapy, the second was one month after starting phototherapy and the third was 3 months after NB-UVB sessions within 30 minutes after last exposure. Each sample was $5 \mathrm{ml}$ venous blood, obtained from every patient using a wide-pore syringe to avoid hemolysis of the red blood corpuscles and protected from light, allowed to clot completely (within 30-60 minutes) at the room temperature. Centrifugation was done at 5,000 rpm for 5-10 minutes to separate the serum. Serum was separated and stored at $-20^{\circ} \mathrm{C}$ until analyzed.

Prolactin assay (electro-chemiluminescence immunoassay "ECLIA" Sandwich technique): Sample and a biotinylated monoclonal prolactin-specific antibody form a first complex. After addition of a monoclonal prolactin-specific antibody labeled with a ruthenium complex and streptavidin-coated microparticles, a-sandwich complex is formed and becomes bound to the solid phase via interaction of biotin and streptavidin

Results were determined via a calibration curve which is instrument-specifically generated by 2 -point calibration and a master curve provided via the reagent barcode.

IgE assay (particle-enhanced immunonephlometry): Polystyrene particles coated with specific antibodies to human IgE are aggregated when mixed with samples containing human IgE. These aggregates scatter a beam of light passed through the sample. The intensity of the scattered light is proportional to the concentration of the receptive protein in the sample. The result is evaluated by comparison with a standard of known concentration.

\section{Statistical analysis}

Data were coded manually and analysis was conducted through SPSS program, version 16. The results were presented in tables. Descriptive and analytical statistical analysis was done: Quantitative data; mean \pm standard deviation $(S D)$ were used. Qualitative data: number and percentage were used. Chi square $\left(\chi^{2}\right)$ test was used for comparison of qualitative data, paired student's t-test for quantitative data of two samples. Analysis of variance (ANOVA) was used for comparison of quantitative data of more than two groups. Regression analysis was carried out to assess correlation between PASI score and PRL and IgE levels. The level of significance was taken at $P<0.05$.

\section{Results}

The psoriatic patients were 50; $35(70 \%)$ males and $15(30 \%)$ females. Their age ranged from 15-68 years with a mean of $41.68 \pm$ 12.69 years 
All selected patients were presented with chronic plaque psoriasis located in different sites. The duration of the disease ranged from 1-16 years with a mean of $6.46 \pm 3.52$.

Patients were classified according to their PASI score into three classes mild, moderate and severe. They were 12 (24\%) mild, 28 (56\%) moderate and $10(20 \%)$ severe before NB-UVB therapy and were 46 (92\%) mild, 3 (6\%) moderate and 1 (2\%) severe after NB-UVB therapy. The means of PASI scores were $15.58 \pm 8.10$ and $5.79 \pm 4.18$ before and after NB-UVB therapy, respectively. The differences between severities of cases and mean scores were significant before $(\mathrm{P}=0.01)$ and after $(\mathrm{P}=0.01)$ NB-UVB therapy (Table 1$)$.

Table 2 showed a statistically significant difference between patients before and one month after NB-UVB therapy regarding prolactin level $(\mathrm{P}=0.01)$ and insignificant difference before and three months after NB-UVB therapy $(\mathrm{P}=0.06)$. Also, the table showed a statistically significant difference between patients before and three months after NB-UVB therapy regarding IgE level $(\mathrm{P}=0.0003)$.

Table 3 cleared a statistically insignificant correlation between PASI score and prolactin level before and after NB-UVB therapy versus a statistically significant correlation between PASI score and IgE level after NB-UVB therapy.

Table 4 observed statistically insignificant relation between PASI score before UVB and both age and sex. Also, the table showed statistically insignificant relation between PASI score after UVB and both age and sex.

Table 5 cleared statistically insignificant relation between PASI

\begin{tabular}{|c|c|c|c|c|c|c|}
\hline \multirow{3}{*}{ Severity } & \multicolumn{4}{|c|}{ PASI $(n=50)$} & \multirow{3}{*}{$\mathbf{x}_{\mathbf{t}^{*}}$} & \multirow{3}{*}{ p } \\
\hline & \multicolumn{2}{|c|}{ Before UVB } & \multicolumn{2}{|c|}{ After UVB } & & \\
\hline & No. & $\%$ & No. & $\%$ & & \\
\hline Mild & 12 & 24.0 & 46 & 92.0 & & \\
\hline Moderate & 28 & 56.0 & 3 & 6.0 & & \\
\hline Severe & 10 & 20.0 & 1 & 2.0 & 47.46 & 0.000 \\
\hline Mean \pm SD & \multicolumn{2}{|c|}{$15.58 \pm 8.10$} & \multicolumn{2}{|c|}{$5.79 \pm 4.18$} & $-7.59^{\star}$ & 0.000 \\
\hline
\end{tabular}

Table 1: Comparison between psoriasis area and severity index (PASI) before and after UVB.

\begin{tabular}{|c|c|c|c|}
\hline \multirow{3}{*}{ Variable } & \multicolumn{3}{|c|}{ Psoriasis patients $(n=50)$} \\
\hline & \multicolumn{3}{|c|}{ PRL $(n=50)$} \\
\hline & Before UVB & $\begin{array}{c}1 \text { month after } \\
\text { UVB }\end{array}$ & 3 months after UVB \\
\hline PRL: Mean \pm SD & $20.70 \pm 5.50$ & $19.45 \pm 5.27$ & $17.76 \pm 5.74$ \\
\hline Test of significance & & $\mathrm{t} 1=-1.16, P=0.012$ & $\mathrm{t} 2=-1.534, P=0.06$ \\
\hline & \multicolumn{3}{|c|}{$\lg E(n=50)$} \\
\hline IgE: Mean \pm SD & $370.14 \pm 265.16$ & $327.40 \pm 239.88$ & $218.14 \pm 147.34$ \\
\hline Test of significance & & $\mathrm{t} 3=-0.845, P=0.2$ & $\mathrm{t} 4=-3.543, P=0.0003$ \\
\hline
\end{tabular}

Table 2: Comparison between prolactin (PRL) and IgE before and after UVB. t1: Difference between PRL before UVB and one month after UVB; t2: Difference between PRL before UVB and three months after UVB; t3: Difference between IgE before UVB and one month after UVB; t4: Difference between Ige before UVB and three months after UVB.

\begin{tabular}{|c|c|c|}
\hline & $\mathbf{r}_{\mathbf{s}}$ & $\boldsymbol{p}$ \\
\hline PASI vs PRL Before UVB & -0.096 & 0.506 \\
\hline PASI vs IgE Before UVB & 0.255 & 0.074 \\
\hline PASI vs PRL after 1 month UVB & -0.106 & 0.466 \\
\hline PASI vs PRL after 3 month UVB & -0.038 & 0.793 \\
\hline PASI vs IgE after 1 month UVB & 0.274 & 0.054 \\
\hline PASI vs IgE after 3 month UVB & $0.360^{+}$ & $0.01^{*}$ \\
\hline
\end{tabular}

Table 3: Correlation between psoriasis area and severity index (PASI) with prolactin (PRL) and IgE. rs: Spearman coefficient; ${ }^{*}$ : Statistically significant at $\mathrm{P}<0.05$.

\begin{tabular}{|c|c|c|c|c|c|c|c|c|}
\hline \multirow{3}{*}{ Variables } & \multicolumn{6}{|c|}{ PASI Before UVB $(n=50)$} & \multirow{3}{*}{$\begin{array}{c}F \text { test }^{\star} \\
X^{2 * *} \\
t \text { test } \\
F^{\star \star *}\end{array}$} & \multirow{3}{*}{$p$} \\
\hline & \multicolumn{2}{|c|}{$\begin{array}{c}\text { Mild } \\
(n=12)\end{array}$} & \multicolumn{2}{|c|}{$\begin{array}{c}\text { Moderate } \\
(n=28)\end{array}$} & \multicolumn{2}{|c|}{$\begin{array}{l}\text { Severe } \\
(n=10)\end{array}$} & & \\
\hline & No. & $\%$ & No. & $\%$ & No. & $\%$ & & \\
\hline $\begin{array}{c}\text { Age (years) } \\
\text { Mean } \pm S D\end{array}$ & \multicolumn{2}{|c|}{$38.17 \pm 13.86$} & \multicolumn{2}{|c|}{$43.04 \pm 11.65$} & \multicolumn{2}{|c|}{$42.10 \pm 14.59$} & $F^{*}=0.615$ & 0.545 \\
\hline $\begin{array}{c}\text { Sex } \\
\text { Male } \\
\text { Female }\end{array}$ & $\begin{array}{l}8 \\
4\end{array}$ & $\begin{array}{l}66.7 \\
33.3\end{array}$ & $\begin{array}{c}20 \\
8\end{array}$ & $\begin{array}{l}71.4 \\
28.6\end{array}$ & $\begin{array}{l}7 \\
3\end{array}$ & $\begin{array}{l}70.0 \\
30.0\end{array}$ & $X^{2^{* *}}=0.091$ & 0.95 \\
\hline \multirow[t]{2}{*}{ Variables } & \multicolumn{2}{|c|}{$\begin{array}{c}\text { Mild } \\
(n=46)\end{array}$} & \multicolumn{2}{|c|}{$\begin{array}{c}\text { Moderate } \\
(n=3)\end{array}$} & \multicolumn{2}{|c|}{$\begin{array}{c}\text { Severe } \\
(n=1)\end{array}$} & & \\
\hline & No. & $\%$ & No. & $\%$ & No. & $\%$ & & \\
\hline $\begin{array}{c}\text { Age (years) } \\
\text { Mean } \pm S D\end{array}$ & \multicolumn{2}{|c|}{$41.89 \pm 12.76$} & \multicolumn{2}{|c|}{$38.67 \pm 16.50$} & \multicolumn{2}{|c|}{$41.0^{\#}$} & $\begin{array}{c}\mathrm{t}^{\star * * *}= \\
-0.332\end{array}$ & 0.38 \\
\hline $\begin{array}{l}\text { Sex } \\
\text { Male }\end{array}$ & 32 & 69.6 & 2 & 66.7 & 1 & 100.0 & & \\
\hline Female & 14 & 30.4 & 1 & 33.3 & 0 & 0.0 & FE"\# & 1.0 \\
\hline
\end{tabular}

Table 4: Relation between psoriasis area and severity index (PASI) score before UVB and demographic data. $F^{*}$ : $F$ test (ANOVA); $\mathrm{X}^{2 * *}$ : Value for $\mathrm{Chi}^{2} ; \mathrm{t}^{\star *}$ : test; \#: Excluded from the comparison; FE"\#: Fisher Exact test.

\begin{tabular}{|c|c|c|c|c|c|c|c|c|}
\hline \multirow{3}{*}{ Variable } & \multicolumn{6}{|c|}{ PASI Before UVB $(n=50)$} & \multirow{3}{*}{$\begin{array}{l}X^{2} \\
F^{*} \\
\text { t test }^{\star *}\end{array}$} & \multirow{3}{*}{ p } \\
\hline & \multicolumn{2}{|c|}{$\begin{array}{c}\text { Mild } \\
(n=12)\end{array}$} & \multicolumn{2}{|c|}{$\begin{array}{c}\text { Moderate } \\
(n=28)\end{array}$} & \multicolumn{2}{|c|}{$\begin{array}{l}\text { Severe } \\
(n=10)\end{array}$} & & \\
\hline & No. & $\%$ & No. & $\%$ & No. & $\%$ & & \\
\hline \multicolumn{9}{|l|}{$\begin{array}{c}\text { Disease duration } \\
\text { (years) }\end{array}$} \\
\hline$<6$ & 6 & 50.0 & 13 & 46.4 & 4 & 40.0 & \multirow[b]{3}{*}{$x^{2}=1.201$} & \multirow[b]{3}{*}{0.877} \\
\hline $6-12$ & 6 & 50.0 & 13 & 46.4 & 5 & 50.0 & & \\
\hline$>12$ & 0 & 0.0 & 2 & 7.1 & 1 & 10.0 & & \\
\hline Mean \pm SD & \multicolumn{2}{|c|}{$5.25 \pm 2.86$} & \multicolumn{2}{|c|}{$6.89 \pm 3.57$} & \multicolumn{2}{|c|}{$6.70 \pm 4.08$} & $F^{*}=1.547$ & 0.461 \\
\hline \multirow{3}{*}{ Variable } & \multicolumn{6}{|c|}{ PASI after UVB $(n=50)$} & & \\
\hline & \multicolumn{2}{|c|}{$\begin{array}{l}\text { Mild } \\
(n=46)\end{array}$} & \multicolumn{2}{|c|}{$\begin{array}{l}\text { Moderate } \\
(n=3)\end{array}$} & \multicolumn{2}{|c|}{$\begin{array}{c}\text { Severe } \\
(n=1)\end{array}$} & $\underset{\mathrm{F}^{*}}{\mathrm{X}^{2}}$ & $\mathbf{p}$ \\
\hline & No. & $\%$ & No. & $\%$ & No. & $\%$ & & \\
\hline \multicolumn{9}{|l|}{$\begin{array}{c}\text { Disease duration } \\
\text { (years) }\end{array}$} \\
\hline$<6$ & 21 & 45.7 & 2 & 66.7 & 0 & 0.0 & & \\
\hline $6-12$ & 23 & 50.0 & 0 & 0.0 & 1 & 100.0 & & \\
\hline$>12$ & 2 & 4.3 & 1 & 33.3 & 0 & 0.0 & $x^{2}=6.786$ & 0.14 \\
\hline Mean \pm SD & \multicolumn{2}{|c|}{$6.46 \pm 3.4$} & \multicolumn{2}{|c|}{$6.33 \pm 6.11$} & \multicolumn{2}{|c|}{$70.0^{\#}$} & $t=-0.036$ & 0.487 \\
\hline
\end{tabular}

Table 5: Relation between psoriasis area and severity index (PASI) before UVB with disease duration. $X^{2}$ : Value for Chi square; $F^{*}$ : $F$ test (ANOVA); $t^{* *}$ : Value for test; \#: Excluded from the comparison.

score before UVB and disease duration. Also, the table showed statistically insignificant relation between PASI score after UVB and disease duration.

Table 6 observed a statistically insignificant relation between PASI score before UVB and prolactin levels. The table showed a statistically insignificant relation between PASI score after UVB and prolactin levels.

Table 7 cleared statistically insignificant relation between PASI score before UVB and IgE levels. The table also showed statistically insignificant relation between PASI score after UVB and IgE levels.

\section{Discussion}

Psoriasis is a chronic inflammatory dermatosis. The pathogenesis of psoriasis involves a variety of genetic factors like HLA-C genes and environmental factors like infection, stress, food, or drugs [19].

The etiopathogenesis of psoriasis is still not fully understood. 
Recently, it has been reported that prolactin exerts a proliferative effect on human keratinocytes in vitro and may possibly play a role in the pathogenesis of psoriasis [20].

Also, possible association of serum IgE concentration and psoriasis is reported in some studies, but the finding of IgE concentrations in psoriasis varies widely in different studies [21].

The present study was carried out to estimate serum prolactin and immunoglobulin $\mathrm{E}$ levels in psoriasis vulgaris patients before and after NB-UVB therapy.

Several studies were performed to evaluate the relation between psoriasis severity and prolactin level. Dilme-Carreras et al. [3] carried out a study on 20 patients with plaque-type psoriasis before and after a 6-weeks period of topical treatment. Results were compared with a group of 20 healthy volunteers. The study demonstrated that patients with psoriasis had significantly increased serum PRL levels when compared to healthy controls. Indeed, these findings correspond well to an earlier study that had shown a positive association between raised serum PRL levels and psoriasis. An intriguing new dimension

\begin{tabular}{|c|c|c|c|c|c|}
\hline \multirow[b]{2}{*}{ PRL } & \multicolumn{3}{|c|}{ PASI before UVB $(n=50)$} & \multirow{2}{*}{$\begin{array}{l}F \text { test } \\
\text { ANOVA }\end{array}$} & \multirow[b]{2}{*}{$\boldsymbol{p}$} \\
\hline & $\begin{array}{c}\text { Mild } \\
(n=12)\end{array}$ & $\begin{array}{l}\text { Moderate } \\
(n=28)\end{array}$ & $\begin{array}{l}\text { Severe } \\
(n=10)\end{array}$ & & \\
\hline $\begin{array}{c}\text { Before UVB } \\
\text { Mean } \pm \text { SD }\end{array}$ & $21.86 \pm 4.98$ & $21.01 \pm 5.71$ & $18.46 \pm 5.38$ & 145 & 0.327 \\
\hline $\begin{array}{c}1 \text { month after UVB } \\
\text { Mean } \pm S D\end{array}$ & $19.88 \pm 4.24$ & $19.80 \pm 5.71$ & $\begin{array}{l}17.95 \pm 5.32 \\
1 \quad 1\end{array}$ & 0.497 & 0.611 \\
\hline $\begin{array}{c}3 \text { months after UVB } \\
\text { Mean } \pm \text { SD. }\end{array}$ & $18.27 \pm 4.90$ & $17.50 \pm 6.63$ & $\begin{array}{ll}3 & 17.87 \pm 4.19\end{array}$ & 0.075 & 0.928 \\
\hline \multirow[b]{2}{*}{ PRL } & \multicolumn{3}{|c|}{ PASI after UVB $(n=50)$} & \multirow[b]{2}{*}{ t test } & \multirow[b]{2}{*}{$p$} \\
\hline & $\begin{array}{c}\text { Mild } \\
(n=46)\end{array}$ & $\begin{array}{l}\text { Moderate } \\
(n=3)\end{array}$ & $\begin{array}{l}\text { Severe } \\
\left(n=1^{\#}\right)\end{array}$ & & \\
\hline $\begin{array}{c}\text { Before UVB } \\
\text { Mean } \pm \text { SD }\end{array}$ & $20.69 \pm 5.60$ & $21.47 \pm 5.75$ & 19.0 & 0.228 & 0.575 \\
\hline $\begin{array}{c}1 \text { month after UVB } \\
\text { Mean } \pm S D\end{array}$ & $19.42 \pm 5.38$ & $20.83 \pm 4.77$ & 16.80 & 0.492 & 0.652 \\
\hline $\begin{array}{c}3 \text { months after UVB } \\
\text { Mean } \pm S D\end{array}$ & $17.65 \pm 5.86$ & $18.77 \pm 5.67$ & 19.40 & 0.331 & 0.606 \\
\hline
\end{tabular}

Table 6: Relation between psoriasis area and severity index (PASI) before UVB with prolactin (PRL). \#: Excluded from the comparison; t: Student t-test.

\begin{tabular}{|c|c|c|c|c|c|}
\hline \multirow[b]{2}{*}{$\lg \mathrm{E}$} & \multicolumn{3}{|c|}{ PASI before UVB ( $n=50)$} & \multirow{2}{*}{$\begin{array}{l}F \text { test } \\
\text { ANOVA }\end{array}$} & \multirow[b]{2}{*}{$p$} \\
\hline & $\begin{array}{l}\text { Mild } \\
(n=12)\end{array}$ & $\begin{array}{l}\text { Moderate } \\
(n=28)\end{array}$ & $\begin{array}{l}\text { Severe } \\
(n=10)\end{array}$ & & \\
\hline $\begin{array}{c}\text { Before UVB } \\
\text { Mean } \pm \text { SD }\end{array}$ & $\begin{array}{c}227.58 \pm \\
163.29\end{array}$ & $\begin{array}{c}416.75 \pm \\
298.58\end{array}$ & $\begin{array}{c}410.70 \pm \\
216.99\end{array}$ & 5.171 & 0.075 \\
\hline $\begin{array}{c}1 \text { month after UVB } \\
\text { Mean } \pm S D\end{array}$ & $\begin{array}{c}188.58 \pm \\
122.78\end{array}$ & $\begin{array}{l}368.0 \pm \\
268.18\end{array}$ & $\begin{array}{c}380.30 \pm \\
212.53\end{array}$ & 4.957 & 0.084 \\
\hline $\begin{array}{c}3 \text { months after } \\
\text { UVB } \\
\text { Mean } \pm \text { SD }\end{array}$ & $\begin{array}{c}151.0 \pm \\
65.06\end{array}$ & $\begin{array}{c}223.46 \pm \\
150.38\end{array}$ & $\begin{array}{c}283.80 \pm \\
185.15\end{array}$ & 3.390 & 0.184 \\
\hline \multirow[b]{2}{*}{$\lg E$} & \multicolumn{3}{|c|}{ PASI after UVB ( $n=50)$} & & \\
\hline & $\begin{array}{c}\text { Mild } \\
(n=46)\end{array}$ & $\begin{array}{l}\text { Moderate } \\
(n=3)\end{array}$ & $\begin{array}{c}\text { Severe } \\
\left(n=1^{\#}\right)\end{array}$ & $t$ test & $p$ \\
\hline $\begin{array}{c}\text { Before UVB } \\
\text { Mean } \pm \text { SD }\end{array}$ & $\begin{array}{c}372.15 \pm \\
272.59\end{array}$ & $\begin{array}{c}403.33 \pm \\
174.93\end{array}$ & 178.0 & 0.287 & 0.58 \\
\hline $\begin{array}{c}1 \text { month after UVB } \\
\text { Mean } \pm S D\end{array}$ & $\begin{array}{c}328.04 \pm \\
245.75\end{array}$ & $\begin{array}{c}376.67 \pm \\
177.86\end{array}$ & 150.0 & 0.44 & 0.63 \\
\hline $\begin{array}{c}3 \text { months after } \\
\text { UVB } \\
\text { Mean } \pm S D\end{array}$ & $\begin{array}{c}210.98 \pm \\
142.88\end{array}$ & $340.0 \pm 220.0$ & 182.0 & 1.002 & 0.78 \\
\hline
\end{tabular}

Table 7: Relation between psoriasis area and severity index (PASI) before UVB with IgE. \#: Excluded from the comparison. in the Dilme-Carreras et al. [3] study was the finding that clinical improvement in psoriasis, in response to treatment with topical tacalcitol, was accompanied by a decrease in serum PRL level, and that there was a correlation between serum PRL level and clinical severity as assessed by PASI score. Comparing the results of this study with the results of the present study have showed increased serum prolactin level in the studied group of patients with plaque-type psoriasis vulgaris and decrease of this level after 3 months period of treatment with NB-UVB.

The present study showed also clinical improvement in response to treatment assessed by PASI score but the correlation between serum prolactin level and severity assessed by PASI score was insignificant. ElKhateeb et al. [22] noted that the levels of PRL in blister fluid obtained from involved skin of psoriasis patients were significantly higher than those in blister fluid taken from uninvolved or healthy skin. Moreover, the PRL levels in blister fluid from involved skin were also significantly higher than serum levels in either psoriasis patients or healthy controls. However, there was no correlation between PRL levels in serum/blister fluid from involved skin and PASI score. Also, this last result was consistent with the result of the present study regarding the presence of no correlation between serum PRL level and PASI score.

Malligarjunan et al. [23] confirmed that serum PRL levels were significantly increased in patients with psoriasis when compared to healthy controls. Interestingly, treatment with the anti-thyroid drug propylthiouracil resulted in clinical improvement in psoriasis, which again correlated with significantly decreased serum PRL levels. On the other hand, this last result was against the result of the present study regarding the presence of a correlation between serum PRL level and PASI score.

In common with each of the three studies outlined, the sample size was relatively small which means further studies with larger numbers of patients are required to confirm each of these findings [4].

In another study by Handjani et al. [20] there was no significant difference in the serum prolactin level among patients with psoriasis vulgaris and the control group. This is against the results of the present study, which showed increased serum prolactin level in psoriasis patients. Also, there was no relationship between the severity of psoriasis vulgaris, as exhibited by the PASI score, and serum prolactin levels. These results were consistent with the results of the present study. In this last study they concluded that studies with larger sample sizes are still necessary, to further study the role of prolactin in the pathogenesis of psoriasis.

Also, several studies were performed to evaluate the relation between psoriasis severity and IgE level. Del Puerto et al. [24] reported a higher concentration of serum IgE in patients with psoriasis and no statistical relationship between serum IgE concentrations and psoriasis severity. Comparing the results of this study with the results of the present study, the present study showed increased serum IgE level in the studied group of patients with plaque-type psoriasis vulgaris and decrease of this level after 3 months period of treatment with NB-UVB.

The present study showed also clinical improvement in response to treatment assessed by PASI score but there was a significant correlation between serum IgE level and severity assessed by PASI score. OvcinaKurtovic and Kasumagic-Halilovic [25] found the higher concentration of serum IgE concentration in patients with psoriasis than the normal population, however reported a higher concentration of serum $\operatorname{IgE}$ in more severe cases. In this study they compared cases with chronic plaque psoriasis (CPP) with those with psoriatic erythroderma (PE). The serum IgE level was found to be elevated in $77 \%$ of the psoriatic $\mathrm{PE}$ group, which is much higher than that $(29.7 \%)$ of CPP group $(p<0.05)$. 
It is worth mentioning in the latter study the PASI were not used to assess disease severity.

In a study done by Ding et al. [26] the levels of IgE in patients with generalized pustulr psoriasis (GPP) and patients with PV were compared with those of healthy controls. The percentage of patients with GPP who had increased IgE levels was significantly higher than that of patients with PV and of healthy controls. The mean levels of IgE were also higher in the GPP group. They hypothesized that serum IgE level is a general indicator for increased inflammation in GPP and PV.

This is consistent with present study regarding the presence of increased serum IgE level in patients with PV.

Li et al. [8] performed a study on serum immunoglobulins in psoriatic erythroderma. Serum IgE level was found to be elevated in psoriatic erythroderma patients than the controls.

Lajevardi et al. [21] found in their study that serum $\operatorname{IgE}$ concentrations were not greater in patients with psoriasis. IgE concentration is also was not associated with the severity of psoriasis based on the PASI score, therefore, they considered that the role of IgE in psoriasis can be considered insignificant as some previous studies indicate and this against the results of the present study that showed increased serum IgE level in patients with psoriasis and significant correlation between IgE level and psoriasis severity assessed by PASI score.

From the previous reports, we can hypothesis that prolactin is one of a pituitary hormones has a strong relationship with the pathology of psoriasis while IgE is secondary response to skin lesion injury. The effective role of UV therapy is gust locally on skin lesion. So, $\operatorname{IgE}$ is corrected after UV therapy while prolactin is not. This also can explain why most of patients have got relapsing after a short period of therapy.

\section{Conclusion}

The present study concluded that serum prolactin level is elevated in psoriasis vulgaris but there is no significant correlation of its level with psoriasis severity. Also, serum IgE level is elevated in psoriasis vulgaris and there is a significant correlation between its levels with psoriasis severity.

\section{References}

1. Gelfand JM, Neimann AL, Shin DB, Wang X, Margolis DJ, et al. (2006) Risk of myocardial infarction in patients with psoriasis. JAMA 296: 1735-1741.

2. Mehta NN, Azfar RS, Shin DB, Neimann AL, Troxel AB, et al. (2010) Patients with severe psoriasis are at increased risk of cardiovascular mortality: cohort study using the General Practice Research Database. Eur Heart J 31: 1000-1006.

3. Dilme-Carreras E, Martin-Ezquerra G, Sanchez-Regana M, Umbert-Millet $P$ (2011) Serum prolactin levels in psoriasis and correlation with cutaneous disease activity. Clin Exp Dermatol 36: 29-32.

4. Langan EA, Griffiths CE, Paus R (2012) Exploring the role of prolactin in psoriasis. Arch Dermatol Res 304: 115-118.

5. Kanda N, Shimizu T, Tada Y, Watanabe S (2007) IL-18 enhances IFN-gammainduced production of CXCL9, CXCL10, and CXCL11 in human keratinocytes. Eur J Immunol 37: 338-350.

6. Arnold JN, Wormald MR, Sim RB, Rudd PM, Dwek RA (2007) The impact of glycosylation on the biological function and structure of human immunoglobulins. Annu Rev Immunol 25: 21-50.

7. Oettgen HC, Geha RS (2001) IgE regulation and roles in asthma pathogenesis. J Allergy Clin Immunol 107: 429-440.

8. Li LF, Sujan SA, Yang H, Wang WH (2005) Serum immunoglobulins in psoriatic erythroderma. Clin Exp Dermatol 30: 125-127.

9. Pigatto PD (2000) Atopy and contact sensitization in psoriasis. Acta Derm Venereol Suppl (Stockh): 19-20.
10. Geha RS, Jabara HH, Brodeur SR (2003) The regulation of immunoglobulin $E$ class-switch recombination. Nat Rev Immunol 3: 721-732.

11. Bacharier LB, Geha RS (2000) Molecular mechanisms of IgE regulation. J Allergy Clin Immunol 105: S547-558.

12. Walters IB, Ozawa M, Cardinale I, Gilleaudeau P, Trepicchio WL, et al. (2003) Narrowband (312-nm) UV-B suppresses interferon gamma and interleukin (IL) 12 and increases IL-4 transcripts: differential regulation of cytokines at the single-cell level. Arch Dermatol 139: 155-161.

13. Erkin G, Uqur Y, Gurer CK, Asan E, Korkusuz P, et al. (2007) Effect of PUVA narrow-band UVB and cyclosporin on inflammatory cells of the psoriatic plaque. J Cutan Pathol 34: 213-219.

14. Piskin G, Koomen CW, Picavet D, Bos JD, Teunissen MB (2003) Ultraviolet-B irradiation decreases IFN-gamma and increases IL-4 expression in psoriatic lesional skin in situ and in cultured dermal T cells derived from these lesions. Exp Dermatol 12: 172-180.

15. Piskin G, Sylva-Steenland RM, Bos JD, Teunissen MB (2004) T cells in psoriatic lesional skin that survive conventional therapy with NB-UVB radiation display reduced IFN-gamma expression. Arch Dermatol Res 295: 509-516.

16. Naldi L, Gambini D (2007) The clinical spectrum of psoriasis. Clin Dermatol 25: $510-518$

17. Malkic Salihbegovic E, Hadzigrahic N, Cickusic AJ (2015) Psoriasis and metabolic syndrome. Med Arch 69: 85-87.

18. Menter A, Korman NJ, Elmets CA, Feldman SR, Gelfand JM, et al. (2010) Guidelines of care for the management of psoriasis and psoriatic arthritis: Section 5. Guidelines of care for the treatment of psoriasis with phototherapy and photochemotherapy. J Am Acad Dermatol 62: 114-135.

19. Kanda N, Hau CS, Tada Y, Watanabe S (2013) Prolactin May Promote the Development of Psoriasis: Reawakened issue. J Clin Exp Dermatol Res 4: 198

20. Handjani F, Saki N, Ahrari I, Ebrahimi M, Khorrami MM, et al. (2014) Serum prolactin levels in psoriasis vulgaris. ISRN Dermatol 2014: 586049.

21. Lajevardi V, Ghiasi M, Goodarzi A, Mohtasham S, Ansari M, et al. (2014) Total serum IgE concentration in patients with psoriasis: a case-control study. Acta Med Iran 52: 515-518.

22. El-Khateeb EA, Zuel-Fakkar NM, Eid SM, Abdul-Wahab SE (2011) Prolactin level is significantly elevated in lesional skin of patients with psoriasis. Int $J$ Dermatol 50: 693-696.

23. Malligarjunan $H$, Gnanaraj $P$, Subramanian $S$, Elango T, Dayalan $H$ (2011) Clinical efficacy of propylthiouracil and its influence on prolactin in psoriatic patients. Clin Biochem 44: 1209-1213.

24. Del Puerto C, De la Cruz C, Avello E (2012): Psoriasis and IgE plasma levels: Lack of correlation with disease severity. J Am Acad Dermatol 66: AB199.

25. Ovcina-Kurtovic N, Kasumagic-Halilovic E (2010) Serum levels of total immunoglobulin $E$ in patients with psoriasis: relationship with clinical type of disease. Med Arh 64: 28-29.

26. Ding $Y, Y i X, Y u N(2013)$ Serum IgE levels are increased in patients with generalized pustular psoriasis. Clin Exp Dermatol 38: 549-552. 